\title{
Comparative study of postoperative analgesia by epidural ketamine and ketamine plus dexamethasone in lower limb orthopedic surgery
}

\author{
Agarwal B. ${ }^{1}$, Jain $\mathrm{P}^{2 *}$
}

DOI: https://doi.org/10.17511/ijmrr.2019.i04.08

\footnotetext{
${ }^{1}$ Babita Agarwal, Assistant Professor, Shri Shankaracharya Institute of Medical Science (SSIMS), Bhilai, Chhattisgarh, India.

2* Pratik Jain, Assistant Professor, Shri Shankaracharya Institute of Medical Science (SSIMS), Bhilai, Chhattisgarh, India.
}

\begin{abstract}
Aim \& Objectives: To compared the effect of ketamine and combination of ketamine plus dexamethasone on the duration of postoperative analgesia and to evaluate the effect of dexamethasone on postepidural backache and other complications. Methods: 50 patients (ASA I and II) posted for elective surgery of lower limb in orthopedics, were divided at random into two groups of 25 each. Patients in group I received Inj. Ketamine $\mathrm{HCl} 0.3 \mathrm{mg} / \mathrm{kg}$ diluted in $10 \mathrm{ml}$ normal saline while patients in group II received ketamine $\mathrm{HCl} 0.3 \mathrm{mg} / \mathrm{kg}$ and dexamethasone $8 \mathrm{mg}$ diluted in $10 \mathrm{ml}$ normal saline postoperatively through epidural catheter. The relief of pain and perioperative sequelae were compared. Results: Groups were compared with respect to quality of epiduralanaesthesia and pain relief as felt by the patient. The quality of epidural anaesthesia was found adequate in $80 \%$ cases of group 2 and $76 \%$ cases of group 1 . Pain relief was $20 \%$ excellent and $76 \%$ good in group 2 and $12 \%$ excellent and $68 \%$ good in group 1 . In group I the mean duration of pain relief after epidural injection of ketamine $0.3 \mathrm{mg} / \mathrm{kg}$ was $363.91 \pm 180.94 \mathrm{~min}$ and in group II after epidural injection of ketamine $0.3 \mathrm{mg} / \mathrm{kg}$ with dexamethasone $8 \mathrm{mg}$ was $582.63 \pm 182.03 \mathrm{~min}$. These values differ markedly and are statistically highly significant $(p<0.001)$. Conclusion: Ketaminecan be used epidurally safely for rapid onset and is effective for prolonged postoperative analgesia with minimum side effects and high acceptability. The duration can be further prolonged with the addition of dexamethasone and the incidence of postepidural backache is also minimised with dexamethasone.
\end{abstract}

Keywords: Analgesics, Ketamine, Anaesthetic techniques, Epidural injection

Corresponding Author

Pratik Jain, Assistant Professor, Shri Shankaracharya Institute of Medical Science (SSIMS), Bhilai, Chhattisgarh, India.

Email: dr_pratik_jain@yahoo.com
How to Cite this Article

To Browse

Agarwal B, Jain P. Comparative study of postoperative analgesia by epidural ketamine and ketamine plus dexamethasone in lower limb orthopedic surgery. Int J Med Res Rev. 2019;7(4):300-308

Available From

https://ijmrr.medresearch.in/index.php/ijmrr/article/ view/1073

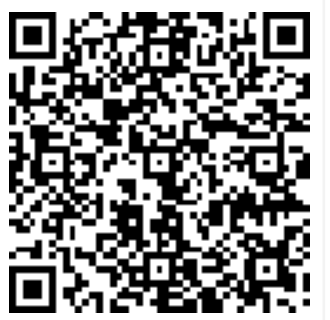

\footnotetext{
(1)
}




\section{Introduction}

Pain is the most common complaint for which the patient seeks medical assistance, as it is one of the most distressing and compelling experience. Man has sought relief from this most distressing agony by various pharmacological \& non pharmacological methods. Herbal concoctions, \& extracts, alcohol \& narcotics have been tried to alleviate pain.

The relief of pain during surgery is the Raison-d-etre of Anaesthesia which should appropriately be extended into the postoperative period but it is often under-estimated \& under treated because patients often accept pain as an inevitable part of surgical experience $\&$ fails to seek relief [1].

The incidence of post-operative pain varies with each individual but is largely governed by the site, nature \& duration/depth of operation. Upper abdominal \& thoracic operations are most painful \& are associated with increased incidence of postoperative pulmonary complications \& hypoxemia [2].

Regional block produces satisfactory anaesthesia \& analgesia along with profound muscle relaxation. Simpson et al (1961) \& Bromage (1967) emphasized the superiority of epidural anaesthesia over other techniques for postoperative analgesia.

The complete pain relief which results from this block permits more effective coughing better ventilation and increased mobility. It prevents the possible serious neurological sequelae, hypotension, bradycardia due to spinal anesthesia and the physiological and metabolic alterations induced by general anaesthesia. [2].

Ketamine, a derivate of phencyclidine noncompetitive N-methyl-D-asparatate (NMDA) receptor antagonist is a general anaesthetic agent and in sub anaesthetic doses.

It provides marked analgesia without inducing respiratory depression. Since the first publication on the epidural ketamine by the epidural \& intrathecal route have been published.

Some authors studied the effect of epidural dexamethasone on the incidence of post epidural backache after non obstetric surgery and concluded that the epidural dexamethasone reduced the incidence and severity of post epidural backache [3].
Only few studies have been carried out with encouraging results and the study is proposed to evaluate the postoperative pain relief by epidural ketamine and the effect of adding dexamethasone on duration of analgesia and perioperative sequelae [1-5].

\section{Materials and Methods}

Setting, duration and type of study: The present clinical study of postoperative analgesia by epidural ketamine and combination of ketamine and dexamethasone was conducted in the department of anaesthesiology, Shri Shankaracharya Institute of Medical Science, Junwani, Bhilai over a span of two years.

Sampling methods, sample size: The study was conducted on 50 patients of ASA grade I or II of either sex in the age group of 20-70 years, undergoing elective orthopedic surgery of lower limb.

Inclusion criteria: Pre-anaesthetic evaluation was done a day before surgery.

Through physical and systemic examination, routine investigations, specific investi-gations in some patient like chest X-ray, ECG, blood sugar \& blood urea, liver function test, $\mathrm{X}$-ray spine were performed to rule out any disorder affecting the cardiovascular, respiratory, renal, hepatic endocrinal or neurological systems,

Exclusion criteria: Patients with chronic history of headache, backache, infection and drug addiction were excluded from the study. The technique was explained to every patient and an informed consent was taken.

Data collection: The cases were divided at random into two groups of 25 each and in the postoperative period after the weaning of conventional epidural anaesthesia when the patient complained of pain group I received $0.3 \mathrm{mg} / \mathrm{kg}$ ketamine $\mathrm{HCl}$ and group II $0.3 \mathrm{mg} / \mathrm{kg}$ ketamine $\mathrm{HCl}$ and $8 \mathrm{mg}$ dexamethasone diluted in $10 \mathrm{ml}$ normal saline through the epidural catheter and repeated on demand.

Epidural catheter was removed after 48 hours under all aseptic precautions and a seal of band-aid applied.

Technique: Patient was taken on the operation table. Vital parameters pulse, blood pressure and respiratory rate recorded. 
Epidural catheter $16 \mathrm{G}$ was then passed through the needle and directed caudally.

The patient was made supine and a test dose of local anaesthetic was injected after aspiration to detect any accidental subarachnoid or intravascular placement of the catheter.

If all was well then the total dose of $20 \mathrm{ml}$ local anaesthetic $(12 \mathrm{ml} \quad 2 \%$ xylocaine $+8 \mathrm{ml} \quad 0.5 \%$ sensorcaine) was injected through the catheter slowly enquiring the patient for any paresthesia, dizziness or respiratory distress.

Statistical analysis: Discrete categorical data will be represented in the form of either a number or a percentage, continuous data, assumed to be normally distributed, will be written as either in the form of its mean and standard deviation in the form of its median and interquartile range, as per the requirement.

\begin{tabular}{|c|c|c|c|c|c|c|c|c|c|c|c|c|c|c|c|c|}
\hline \multirow[t]{3}{*}{ Pulse Range/ min } & \multicolumn{4}{|c|}{ Preoperative } & \multicolumn{4}{|c|}{ Interoperative } & \multicolumn{4}{|c|}{ Postoperative } & \multicolumn{4}{|c|}{ Postinjection } \\
\hline & \multicolumn{2}{|c|}{ Group I } & \multicolumn{2}{|c|}{ Group II } & \multicolumn{2}{|c|}{ Group I } & \multicolumn{2}{|c|}{ Group II } & \multicolumn{2}{|c|}{ Group I } & \multicolumn{2}{|c|}{ Group II } & \multicolumn{2}{|c|}{ Group I } & \multicolumn{2}{|c|}{ Group II } \\
\hline & No. & $\%$ & No. & $\%$ & No. & $\%$ & No. & $\%$ & No. & $\%$ & No. & $\%$ & No. & $\%$ & No. & $\%$ \\
\hline $61-70$ & 1 & 4 & 0 & 0 & 1 & 4 & 1 & 4 & 0 & 0 & 0 & 0 & 0 & 0 & 0 & 0 \\
\hline $71-80$ & 10 & 40 & 6 & 24 & 8 & 32 & 7 & 28 & 9 & 36 & 2 & 8 & 6 & 24 & 3 & 12 \\
\hline $81-90$ & 13 & 52 & 12 & 48 & 14 & 56 & 10 & 40 & 16 & 64 & 16 & 64 & 19 & 84 & 17 & 68 \\
\hline $91-100$ & 1 & 4 & 7 & 28 & 2 & 8 & 6 & 24 & 0 & 0 & 7 & 28 & 0 & 0 & 5 & 20 \\
\hline $101-110$ & 0 & 0 & 0 & 0 & 0 & 0 & 0 & 0 & 0 & 0 & 0 & 0 & 0 & 0 & 0 & 0 \\
\hline $111-120$ & 0 & 0 & 0 & 0 & 0 & 0 & 1 & 4 & 0 & 0 & 0 & 0 & 0 & 0 & 0 & 0 \\
\hline Range & \multicolumn{2}{|c|}{$68-92$} & \multicolumn{2}{|c|}{$72-100$} & \multicolumn{2}{|c|}{$62-100$} & \multicolumn{2}{|c|}{$62-100$} & \multicolumn{2}{|c|}{$72-90$} & \multicolumn{2}{|c|}{$76-100$} & \multicolumn{2}{|c|}{ 72-90 } & \multicolumn{2}{|c|}{$76-100$} \\
\hline Mean & \multicolumn{2}{|c|}{80.6} & \multicolumn{2}{|c|}{81.8} & \multicolumn{2}{|c|}{85.0} & \multicolumn{2}{|c|}{85.0} & \multicolumn{2}{|c|}{81.4} & \multicolumn{2}{|c|}{87.0} & \multicolumn{2}{|c|}{82.6} & \multicolumn{2}{|c|}{85.8} \\
\hline SD & \multicolumn{2}{|c|}{ \pm 10.77} & \multicolumn{2}{|c|}{ \pm 9.25} & \multicolumn{2}{|c|}{ \pm 8.71} & \multicolumn{2}{|c|}{ \pm 8.71} & \multicolumn{2}{|c|}{ \pm 9.36} & \multicolumn{2}{|c|}{ \pm 8.49} & \pm 9.1 & & \pm 8.6 & \\
\hline
\end{tabular}

Table-2: Distribution of patients according to respiratory rate at various stages.

\begin{tabular}{|c|c|c|c|c|c|c|c|c|c|c|c|c|c|c|c|c|}
\hline \multirow[t]{3}{*}{ R.R. Range/ min } & \multicolumn{4}{|c|}{ Preoperative } & \multicolumn{4}{|c|}{ Interoperative } & \multicolumn{4}{|c|}{ Postoperative } & \multicolumn{4}{|c|}{ Postinjection } \\
\hline & \multicolumn{2}{|c|}{ Group I } & \multicolumn{2}{|c|}{ Group II } & \multicolumn{2}{|c|}{ Group I } & \multicolumn{2}{|c|}{ Group II } & \multicolumn{2}{|c|}{ Group I } & \multicolumn{2}{|c|}{ Group II } & \multicolumn{2}{|c|}{ Group I } & \multicolumn{2}{|c|}{ Group II } \\
\hline & No. & $\%$ & No. & $\%$ & No. & $\%$ & No. & $\%$ & No. & $\%$ & No. & $\%$ & No. & $\%$ & No. & $\%$ \\
\hline $12-16$ & 15 & 60 & 15 & 60 & 3 & 12 & 7 & 28 & 18 & 72 & 13 & 52 & 15 & 60 & 15 & 60 \\
\hline $17-21$ & 10 & 40 & 10 & 40 & 17 & 68 & 17 & 68 & 7 & 28 & 12 & 48 & 9 & 36 & 10 & 40 \\
\hline $22-26$ & 0 & 0 & 0 & 0 & 5 & 20 & 1 & 4 & 0 & 0 & 0 & 0 & 1 & 4 & 0 & 0 \\
\hline Range & \multicolumn{2}{|c|}{$16-20$} & \multicolumn{2}{|c|}{$14-20$} & \multicolumn{2}{|c|}{$16-22$} & \multicolumn{2}{|c|}{$14-22$} & \multicolumn{2}{|c|}{$14-20$} & \multicolumn{2}{|c|}{$14-20$} & \multicolumn{2}{|c|}{$14-22$} & \multicolumn{2}{|c|}{$14-20$} \\
\hline Mean & \multicolumn{2}{|c|}{16.0} & \multicolumn{2}{|c|}{16.0} & \multicolumn{2}{|c|}{19.4} & \multicolumn{2}{|c|}{17.8} & \multicolumn{2}{|l|}{15.4} & \multicolumn{2}{|c|}{16.4} & \multicolumn{2}{|c|}{16.2} & \multicolumn{2}{|l|}{16.0} \\
\hline SD & \multicolumn{2}{|c|}{ \pm 1.75} & \multicolumn{2}{|c|}{ \pm 1.75} & \multicolumn{2}{|c|}{ \pm 1.42} & \multicolumn{2}{|c|}{ \pm 1.47} & \multicolumn{2}{|c|}{ \pm 1.88} & \multicolumn{2}{|c|}{ \pm 1.67} & \multicolumn{2}{|c|}{ \pm 1.77} & \pm 1.7 & \\
\hline
\end{tabular}

After epidural injection of ketamine $\mathrm{HCl}$ in group I and ketamine with dexamethasone in group II, there was no significant changes in respiratory rate which has been proved statistically $(p>0.05)$.

Table-3: Distribution of patients according to systolic blood pressure at various stages.

\begin{tabular}{|c|c|c|c|c|c|c|c|c|c|c|c|c|c|c|c|c|}
\hline \multirow[t]{3}{*}{ R.R. Range/ min } & \multicolumn{4}{|c|}{ Preoperative } & \multicolumn{4}{|c|}{ Interoperative } & \multicolumn{4}{|c|}{ Postoperative } & \multicolumn{4}{|c|}{ Postinjection } \\
\hline & \multicolumn{2}{|c|}{ Group I } & \multicolumn{2}{|c|}{ Grou II } & \multicolumn{2}{|c|}{ Group I } & \multicolumn{2}{|c|}{ Group II } & \multicolumn{2}{|c|}{ Group I } & \multicolumn{2}{|c|}{ Group II } & \multicolumn{2}{|c|}{ Group I } & \multicolumn{2}{|c|}{ Group II } \\
\hline & No. & $\%$ & No. & $\%$ & No. & $\%$ & No. & $\%$ & No. & $\%$ & No. & $\%$ & No. & $\%$ & No. & $\%$ \\
\hline $90-100$ & 2 & 8 & 1 & 4 & 1 & 4 & 2 & 8 & 1 & 4 & 1 & 4 & 0 & 0 & 0 & 0 \\
\hline $101-110$ & 7 & 28 & 7 & 28 & 7 & 28 & 6 & 24 & 6 & 24 & 4 & 16 & 5 & 20 & 6 & 24 \\
\hline $111-120$ & 9 & 36 & 10 & 40 & 9 & 36 & 12 & 48 & 11 & 44 & 13 & 52 & 12 & 48 & 10 & 40 \\
\hline
\end{tabular}




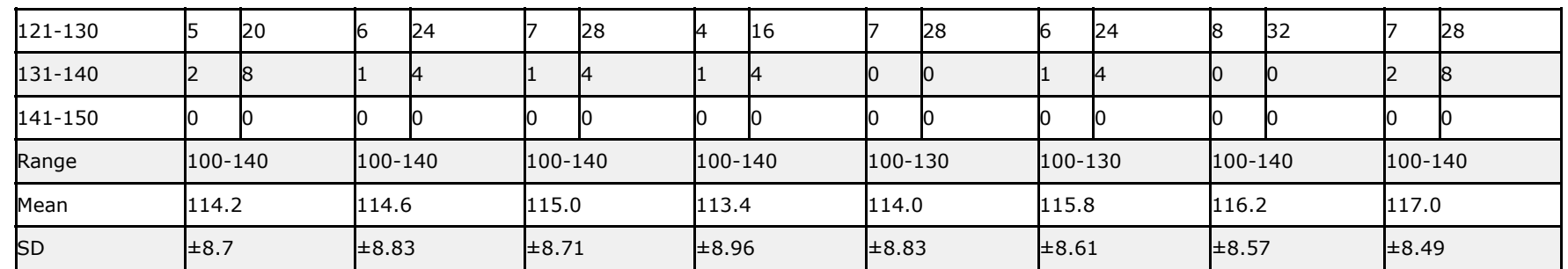

On comparison there is no statistically significant $(p>0.05)$ change in systolic BP after epidural injection of either ketamine $\mathrm{HCl}$ or ketamine $\mathrm{HCl} \&$ dexamethasone.

Table-4: Distribution of patients according to level of sensory block.

\begin{tabular}{|l|l|l|l|l|}
\hline \multirow{2}{*}{ Level of block (Spinal Segment) } & \multicolumn{2}{|c|}{ Group I } & \multicolumn{2}{|c|}{ Group II } \\
\cline { 2 - 6 } & No. & $\%$ & No & $\%$ \\
\hline T6 & 0 & 0 & 0 & 0 \\
\hline$T 7$ & 2 & 8 & 0 & 0 \\
\hline$T 8$ & 8 & 32 & 9 & 36 \\
\hline$T 9$ & 0 & 0 & 2 & 8 \\
\hline$T 10$ & 13 & 52 & 11 & 44 \\
\hline$T 11$ & 0 & 0 & 0 & 0 \\
\hline$T 12$ & 2 & 8 & 3 & 12 \\
\hline L1 & 0 & 0 & 0 & 0 \\
\hline
\end{tabular}

The table shows distribution of patients according to the level of sensory block in the two groups. The level of sensory block attained was T7 to T12 in both the groups which was corresponded to the type of surgery in each case.

Table No.-5: Distribution of patients according to quality of epidural anaesthesia

\begin{tabular}{|l|l|l|l|l|}
\hline \multirow{2}{*}{ Quality of epidural anaesthesia } & \multicolumn{2}{|c|}{ Group I } & \multicolumn{2}{c|}{ Group II } \\
\cline { 2 - 6 } & No. & $\%$ & No & $\%$ \\
\hline Adequate & 19 & 76 & 20 & 80 \\
\hline Patchy/Partial & 6 & 24 & 5 & 20 \\
\hline No effect & 0 & 0 & 0 & 0 \\
\hline
\end{tabular}

\section{Quality of epidural anaesthesia}

Adequate- patient was comfortable, no pain during surgery

Patchy/Partial- patient felt slight pain at any time during surgery.

No effect- surgery could not be allowed under epidural anaesthesia, G.A. required.

Table No-6: Distribution of patients according to onset of pain relief after epidural injection of ketamine HCL or ketamine HCL and dexamethasone.

\begin{tabular}{|l|l|l|l|l|}
\hline \multirow{2}{*}{ Range of Onset $(\mathrm{min})$} & \multicolumn{2}{|c|}{ Group I } & \multicolumn{2}{c|}{ Group II } \\
\cline { 2 - 6 } & No. & $\%$ & No & $\%$ \\
\hline $1-3$ & 0 & 0 & 0 & 0 \\
\hline $4-6$ & 10 & 40 & 12 & 48 \\
\hline $7-9$ & 11 & 44 & 8 & 32 \\
\hline $10-12$ & 4 & 16 & 5 & 20 \\
\hline $13-15$ & 0 & 0 & 0 & 0 \\
\hline No relief & 0 & 0 & 0 & 0 \\
\hline Range & $5-12$ & $5-12$ \\
\hline Mean & 7.28 & 7.16 \\
\hline SD & \pm 1.92 & \pm 1.93 \\
\hline P value & $>0.05$ & \\
\hline
\end{tabular}

The mean onset of pain relief in group I was $7.28 \pm 1.92 \mathrm{~min}$ and in group II was $7.16 \pm 1.93 \mathrm{~min}$. The values are comparable and statistically not significant $(p>0.05)$.

Table No.-7: Distribution of patients according to duration of pain relief post injection

\begin{tabular}{|l|l|l|l|l|}
\hline \multirow{2}{*}{ Duration of pain relief $(\mathrm{min})$} & \multicolumn{3}{|c|}{ Group I } & \multicolumn{2}{c|}{ Group II } \\
\cline { 2 - 6 } & No. & $\%$ & No & $\%$ \\
\hline No relief & 0 & 0 & 0 & 0 \\
\hline $1-180$ & 2 & 8 & 0 & 0 \\
\hline $181-360$ & 12 & 48 & 2 & 8 \\
\hline $361-540$ & 4 & 16 & 4 & 16 \\
\hline $541-720$ & 5 & 24 & 11 & 44 \\
\hline $721-900$ & 0 & 0 & 1 & 4 \\
\hline $901-1080$ & 0 & 0 & 1 & 4 \\
\hline No pain & 2 & 8 & 6 & 24 \\
\hline Range & $120-720$ & $300-990$ \\
\hline Mean & 363.91 & 582.63 \\
\hline SD & \pm 180.94 & \pm 182.03 \\
\hline P value & $>0.01(\mathrm{HS})$ \\
\hline
\end{tabular}

In group I the mean duration of pain relief after epidural injection of ketamine $0.3 \mathrm{mg} / \mathrm{kg}$ was $363.91 \pm 180.94 \mathrm{~min}$ and in group II after epidural injection of ketamine $0.3 \mathrm{mg} / \mathrm{kg}$ with dexamethasone $8 \mathrm{mg}$ was $582.63 \pm 182.03 \mathrm{~min}$.

These values differ markedly and are statistically highly significant $(p<0.001)$.

Table No.-8: Distribution of patients according to quality of pain relief postinjection 


\begin{tabular}{|l|l|l|l|l|}
\hline \multirow{2}{*}{ Degree of pain relief $(\mathrm{min})$} & \multicolumn{2}{c|}{ Group I } & \multicolumn{2}{c|}{ Group II } \\
\cline { 2 - 6 } & No. & $\%$ & No & $\%$ \\
\hline Excellent & 3 & 12 & 5 & 20 \\
\hline Good & 17 & 68 & 19 & 76 \\
\hline Fair & 5 & 20 & 1 & 4 \\
\hline Poor & 0 & 0 & 0 & 0 \\
\hline
\end{tabular}

\section{Quality of pain relief post injection}

Excellent- No pain, patient comfortable.

Good- Pain reported on questioning

Fair- patient draws nurse's attention to pain.

Poor- patient in agony and crying with pain.

Table-9: Distribution of patients according to side effects at various stages.

\begin{tabular}{|c|c|c|c|c|c|c|c|c|c|c|c|c|}
\hline \multirow[t]{3}{*}{ Side effects } & \multicolumn{4}{|c|}{ Intraoperative } & \multicolumn{4}{|c|}{ Postoperative } & \multicolumn{4}{|c|}{ Postinjection } \\
\hline & \multicolumn{2}{|c|}{ Group I } & \multicolumn{2}{|c|}{ Group } & \multicolumn{2}{|c|}{ Group I } & \multicolumn{2}{|c|}{ Group II } & \multicolumn{2}{|c|}{ Group I } & \multicolumn{2}{|c|}{ Group II } \\
\hline & No. & \& & No. & \& & No. & $\&$ & No. & \& & No. & \& & No. & \& \\
\hline Pain & 6 & 24 & 5 & 20 & 0 & 0 & 0 & 0 & 0 & 0 & 0 & 0 \\
\hline Urinary retention & 0 & 0 & 0 & 0 & 0 & 0 & 0 & 0 & 0 & 0 & 0 & 0 \\
\hline Tachycardia & 0 & 0 & 1 & 4 & 0 & 0 & 0 & 0 & 0 & 0 & 0 & 0 \\
\hline Neurological Sequelae & 0 & 0 & 0 & 0 & 0 & 0 & 0 & 0 & 0 & 0 & 0 & 0 \\
\hline Bradycardia & 1 & 4 & 1 & 4 & 0 & 0 & 0 & 0 & 0 & 0 & 0 & 0 \\
\hline Rigors/Shivering & 1 & 4 & 0 & 0 & 0 & 0 & 0 & 0 & 0 & 0 & 0 & 0 \\
\hline Hypotension & 1 & 4 & 0 & 0 & 0 & 0 & 0 & 0 & 0 & 0 & 0 & 0 \\
\hline Respiratory Difficulty & 0 & 0 & 0 & 0 & 0 & 0 & 0 & 0 & 0 & 0 & 0 & 0 \\
\hline Nausea/Vomiting & 0 & 0 & 0 & 0 & 2 & 8 & 2 & 8 & 0 & 0 & 0 & 0 \\
\hline Headache & 0 & 0 & 0 & 0 & 0 & 0 & 0 & 0 & 0 & 0 & 0 & 0 \\
\hline Backache & 0 & 0 & 0 & 0 & 4 & 16 & 0 & 0 & 0 & 0 & 0 & 0 \\
\hline Hallucination & 0 & 0 & 0 & 0 & 0 & 0 & 0 & 0 & 1 & 4 & 0 & 0 \\
\hline None & 17 & 68 & 18 & 72 & 19 & 76 & 23 & 92 & 24 & 96 & 25 & 100 \\
\hline
\end{tabular}

The table shows distribution of patients according to side effects at various stages. The most commonly occurring side effect during intra operative period was pain. Backache occurred in 4 patients during postoperative period in group $I$.

After epidural injection of ketamine $\mathrm{HCl} 0.3 \mathrm{mg} / \mathrm{kg}$ in group I and ketamine $\mathrm{HCl} 0.3 \mathrm{mg} / \mathrm{kg}$ with $8 \mathrm{mg}$ dexamethasone in group II

01. There was no significant changes in pulse rate, systolic \& Diastolic blood pressure respiratory rate, quality of pain relief.

02. The mean onset of pain relief in group I was $7.28 \pm 1.92 \mathrm{~min} \&$ in group II was $7.16 \pm 1.93$ min. These values are Comparable \& Statistically not Significant.

03. In group I the mean duration of pain relief after epidural injection of ketamine $0.3 \mathrm{mg} / \mathrm{kg}$ was $363.91 \pm 180.94 \mathrm{~min}$ and in group II after epidural injection of ketamine $0.3 \mathrm{mg} / \mathrm{kg}$ with dexamethasone $8 \mathrm{mg}$ was $582.63 \pm 182.03 \mathrm{~min}$. These values differ markedly and are statistically highly significant $(p<0.001)$.
04. The most commonly occurring side effect during intra operative period was pain. Backache occurred in 4 patients during postoperative period in group I.

\section{Discussion}

Pain has been defined as an unpleasant sensory and emotional experience associated with actual or potential tissue damage or described in terms of such damage. Pain may serve protective defensive or diagnostic function. But it may be intolerable causing much distress to its bearer.

Whatever be its cause, it is one of the most common symptoms leading the sufferer to seek medical advice demanding relief. The relief of pain during surgery is the "Raison d'etre of anaesthesia" which should appropriately by extended into postoperative period. In this context Hippocrates has said "Divine is the task to relieve pain".

Block BM et al did a meta-analysis on efficacy of postoperative epidural analgesia. They systematically reviewed the efficacy of postoperative epidural analgesia vs parenteral opioids, Inclusion criteria were a comparison of 
Epidural therapy vs parenteral opioids for postoperative analgesia, measurement of pain using a visual analog scale (VAS) or numeric rating scale, Epidural analgesia provided better postoperative analgesia compared with parenteral opioids So ,they concluded that epidural analgesia, regardless of analgesic agent, location of catheter placement, and type and time of pain assessment, provided better postoperative analgesia compared with parenteral opioids [1]. Rigg JR did a randomised trial on epidural anaesthesia and analgesia and outcome of major surgery. Epidural block is widely used to manage major abdominal surgery and postoperative analgesia. Improvement in analgesia, reduction in respiratory failure, and the low risk of serious adverse consequences suggest that many high-risk patients undergoing major intra abdominal surgery will receive substantial benefit from combined general and epidural anaesthesia intra operatively with continuing postoperative epidural [2].

Ameta-analysis was done by Beattie WS et al and conclusion derived that epidural analgesia reduces postoperative myocardial infarction: Postoperative epidural analgesia is considered to have beneficial effects on cardiac outcomes. The authors performed a meta-analysis to determine whether postoperative epidural analgesia continued for more than $24 \mathrm{~h}$ after surgery reduces PMI or in-hospital death [3].

Lavand'homme $P$, De Kock $M$ et al studied that intraoperative epidural analgesia combined with ketamine provides effective preventive analgesia in patients undergoing major digestive surgery. It also seems that intraoperative suppression of spinal sensitization through an effective epidural block is more critical[4]. Suzuki $M$ et al postulated low-dose intravenous ketamine potentiates epidural analgesia after thoracotomy. They concluded that, very-lowdose ketamine infusion as an adjunct to morphine and ropivacaine analgesia during and after thoracotomy seems to reduce persistent pain after thoracotomy.

There were no complications associated with ketamine infusion. Studies on the safety and efficacy of a higher dose of ketamine during surgical manipulation are warranted [5]. This study by Wong CS, Liaw WJ et al evaluated the analgesic efficacy of epidurally co-administered ketamine and morphine in postoperative pain control. Ketamine alone produced no significant pain relief. A 2-mg morphine dose did produce significant analgesia but was accompanied by a high incidence of side effects.
Coadministration of subanalgesic doses of ketamine, $10 \mathrm{mg}$ and morphine, $0.5 \mathrm{mg}$, however, also produced a strong analgesic effect. So they concluded that ketamine, although not itself an epidural analgesic agent potentiates the analgesic effect of morphine, especially when administered as a pretreatment. The resulting lowered dosage of epidural morphine needed for postoperative pain relief reduces, in turn, the incidence of side effects. Pretreatment of patients with ketamine epidurally, followed by injections of combined morphine and ketamine could be a promising new analgesic regimen [6].

Chia YY, Liu $\mathrm{K}$ designed this double-blind study to evaluate the effect of adding small-dose ketamine in a multimodal regimen of postoperative patientcontrolled epidural analgesia (PCEA). The sedation scores and the incidence of side effects (pruritus, nausea, emesis, sleep deprivation, motor block, and respiration depression) were similar between the two groups. The authors concluded that adding ketamine $0.4 \mathrm{mg} / \mathrm{mL}$ in a multimodal PCEA regimen provides better postoperative pain relief and decreases consumption of analgesics. This study demonstrates an additive analgesic effect when ketamine is added to a multimodal analgesic treatment [7].

Naguib $M$ et al studied epidural ketamine for postoperative analgesia. Thirty-four patients of ASA physical status I or II scheduled for gall bladder surgery were studied in a comparative prospective trial to evaluate the efficacy of epidural and intramuscular ketamine for postoperative pain relief. It was concluded that $30 \mathrm{mg}$ epidural ketamine is a safe and effective method for postoperative analgesia [8]. Choe H, Choi YS et al added epidural morphine plus ketamine for upper abdominal surgery and studied improved analgesia from preincisional versus post- incisional administration.

The incidence of adverse effects was not different between the two groups. In conclusion, preoperative administration of morphine and ketamine is more effective in reducing postoperative pain than it is when given during the operation [9]. Thomas $\mathbf{S}$ did work on epidural dexamethasone and found that it reduces postoperative pain and analgesic requirements. This study was undertaken to evaluate the efficacy of epidurally administered dexamethasone in reducing postoperative morphine requirements, as a measure of analgesia following laparoscopic cholecy-stectomy. 
Total morphine consumption for the first $24 \mathrm{hr}$ following surgery was lower in both epidural dexamethasone groups (D1, D2) compared to the control group $(P<0.05)$. So it was concluded that preoperative epidural administration of dexamethasone $5 \mathrm{mg}$, with or without bupivacaine, reduces post-operative pain and morphine consumption following laparoscopic cholecystectomy [10].

Wang YL, Tan PP et al performed a prospective, randomized, double-blind study to compare the effect of epidural dexamethasone on the incidence of postepidural backache after nonobstetric surgery. One thousand un-premedicated, ASA physical status I or II patients scheduled for hemorrhoidectomy were randomly assigned to two groups: Group I patients received $25 \mathrm{~mL} 2 \%$ lidocaine with epinephrine $1: 200,000$ and $1 \mathrm{~mL}$ normal saline epidurally and Group II patients received $25 \mathrm{~mL} 2 \%$ lidocaine with epinephrine $1: 200,000$ and $1 \mathrm{~mL}$ dexamethasone ( $5 \mathrm{mg}$ ) epidurally.

Patients were interviewed at 24,48 , and $72 \mathrm{~h}$ postoperatively using a standard visual analog scale (VAS) for evaluation of postepidural backache. he severity and duration of postepidural backache were significantly decreased in Group II patients. In summary, epidural dexamethasone reduced the incidence and severity of postepidural backache [11]. Khafagy HF, Refaat AI et al compared the efficacy of epidural dexamethasone versus fentanyl on postoperative analgesia. Postoperative nausea was significantly lower in the BD group versus the $B$ and BF groups $(p<0.05)$. This study revealed that epidural bupivacaine-dexamethasone admixture had almost the same analgesic potency as bupivacaine-fentanyl with opioid-sparing and antiemetic effects. Similar study by Naghipour BA et al also studied and concluded that dexamethasone added to bupivacaine prolongs duration of epidural analgesia $[12,13]$.

Wang LZ, Hu XX et al on the other hand studied influence of epidural dexamethasone on maternal temperature and serum cytokine concentration after labor epidural analgesia. Maternal tympanic temperature was measured before epidural analgesia and hourly thereafter until delivery. Maternal and cord venous blood were sampled for analysis of interleukin-6 (IL-6), tumor necrosis factor-a, and interleukin-10 levels. There was no difference in the incidence of intrapartum fever (38 ${ }^{\circ} \mathrm{C}$ or more) between the 2 groups.
Epidural dexamethasone alleviates maternal temperature elevation after epidural analgesia. This effect can be attributed to the decrease in IL-6 levels [14]. Buvanendran A et al did work on multimodal analgesia for controlling acute postoperative pain. It is needed for acute postoperative pain management due to adverse effects of opioid analgesics, which can impede recovery; a problem that is of increasing concern with the rapid increase in the number of ambulatory surgeries.

Recent findings Nonsteroidal antiinflam-matory drugs and selective cyclooxygenase- 2 inhibitors consistently reduce postoperative opioid consumption No new adjuvants have appeared in the last year, which robustly reduce opioid consumption and opioid-related adverse effects. To summarize, there is a continuing need to explore new drug combinations to achieve all of the purported goals of multimodal anesthesia[15].

\section{Conclusion}

It is therefore, concluded that the ketamine which is a phencyclidine derivates, NMDA receptor antagonist, general anaesthetic can be used epidurally safely for rapid onset and is effective for prolonged postoperative analgesia with minimum side effects and high acceptability. The duration can be further prolonged with the addition of dexamethasone and the incidence of postepidural backache is also minimised with dexamethasone.

\section{What this study addstothe existing knowledge?}

Use of epidural catheter technique is cheap, feasible, affording good alternative to general anaesthesia avoiding hazards of theatre pollution, providing adequate intraoperative analgesia extending even into postoperative period minimising cumbersome repeated injections for postoperative pain relief. Further study and evaluation of ketamine and dexamethasone using epidural catheter technique for postoperative pain relief is recommended.

\section{Author's contribution}

Dr. Babita Agarwal: Study design, data analysis and manuscript preparation

Dr. Pratik Jain: Study design, data analysis and manuscript preparation 


\section{Reference}

01. Block BM, Liu SS, Rowling son AJ, Cowan AR, Cowan Jr JA, Wu CL. Efficacy of postoperative epidural analgesia- a meta-analysis. Jama. $2003 ; 290(18) 2455-63$.

doi: $10.1001 /$ jama.290.18.2455 [Crossref]

02. Rigg JR, Jamrozik K, Myles PS, Silbert BS, Peyton PJ, Parsons RW, Collins KS. MASTER Anaesthesia Trial Study Group. Epidural anaesthesia and analgesia and outcome of major surgery- a randomised trial. The Lancet. 2002;359(9314)1276-82.doi: 10.1016/ S01406736(02)08266-1 [Crossref]

03. Beattie WS, Badner NH, Choi P. Epidural analgesia reduces postoperative myocardial infarction- a meta-analysis. Anesthes Analges. 2001;93(4)853-8.

[Crossref]

04. Lavand'homme $P$, De Kock $M$, Waterloos $H$. Intraoperative epidural analgesia combined with ketamine provides effective preventive analgesia in patients undergoing major digestive surgery. Anesthe-siology- J Am Soc Anesthesiol. 2005;103(4)813-20.

[Crossref]

05. Suzuki M, Haraguti S, Sugimoto K, Kikutani T, Shimada $Y$, Sakamoto A. Low-dose intravenous ketamine potentiates epidural analgesia after thoracotomy. Anesthesiology- J Am Soc Anesthesiol. 2006;105(1)111-9.

[Crossref]

06. Wong CS, Liaw WJ, Tung CS, Su YF, Ho ST. Ketamine potentiates analgesic effect of morphine in postoperative epidural pain control. Reg Anesth Pain Med. 1996;21(6)534-41. [Crossref]

07. Chia YY, Liu K, Liu YC, Chang HC, Wong CS. Adding ketamine in a multimodal patientcontrolled epidural regimen reduces postoperative pain and analgesic consumption. Anesthes Analges. 1998;86(6)1245-9. doi: 10.1213/00000539-199806000-00021 [Crossref]

08. Naguib M, Adu-Gyamfi Y, Absood GH, Farag $H$, GyasiHK. Epidural ketamine for postoperative analgesia. Canadian Anaesthetists' Soc J. 1986;33(1)16-21.

[Crossref]
09. Choe H, Choi YS, Kim YH, Ko SH, Choi HG, Han $Y$ J et al. Epidural morphine plus ketamine for upper abdominal surgery- improved analgesia from preincisional versus postincisional administration. Anesthes Analges. 1997;84(3)560-3.

[Crossref]

10. Thomas S, Beevi S. Epidural dexamethasone reduces postoperative pain and analgesic requirements. Can J Anesthes. 2006;53(9)899905.

doi: 10.1007/BF03022833 [Crossref]

11. Wang $\mathrm{YL}$, Tan PP, Yang $\mathrm{CH}$, Tsai SC, Chung HS. Epidural dexamethasone reduces the incidence of backache after lumbar epidural anesthesia. Anesthes Analges. 1997;84(2)376-8.

DOI: $\quad 10.1097 / 00000539-19970 \quad 2000-00025$ [Crossref]

12. Khafagy HF, Refaat AI, El-sabae HH, Youssif MA. Efficacy of epidural dexamethasone versus fentanyl on postoperative analgesia. J Anesthes. 2010;24(4)531-6.

doi: $\quad 10.1007 / s 00540-010-0949-7 \quad$ [Crossref]

13. Naghipour BA, Aghamohamadi DA, Azarfarin RA, Mirinazhad MO, Bilehjani EI, Abbasali D, Golzari SE. Dexamethasone added to bupivacaine prolongs duration of epidural analgesia. Middle East J Anesthesiol. 2013;22(1)53-7. [Crossref]

14. Wang LZ, Hu XX, Liu X, Qian P, Ge JM, Tang BL. Influence of epidural dexamethasone on maternal temperature and serum cytokine concentration after labor epidural analgesia. Int J Gynecol Obstet. 2011;113(1)40-3. doi: $10.1016 /$ j.ijgo.2010.10.026 [Crossref]

15. Buvanendran A, Kroin JS. Multimodal analgesia for controlling acute postoperative pain. Current opinion in Anesthesiol. 2009;22(5)588-93. doi: 10.1097/ACO.0b013e328330373a [Crossref] 